\title{
Paediatric Neuroimaging
}

\section{Presentation}

A three and a half year-old male child was referred for neuroimaging under general anaesthesia for intractable seizures. These are selected MR images.

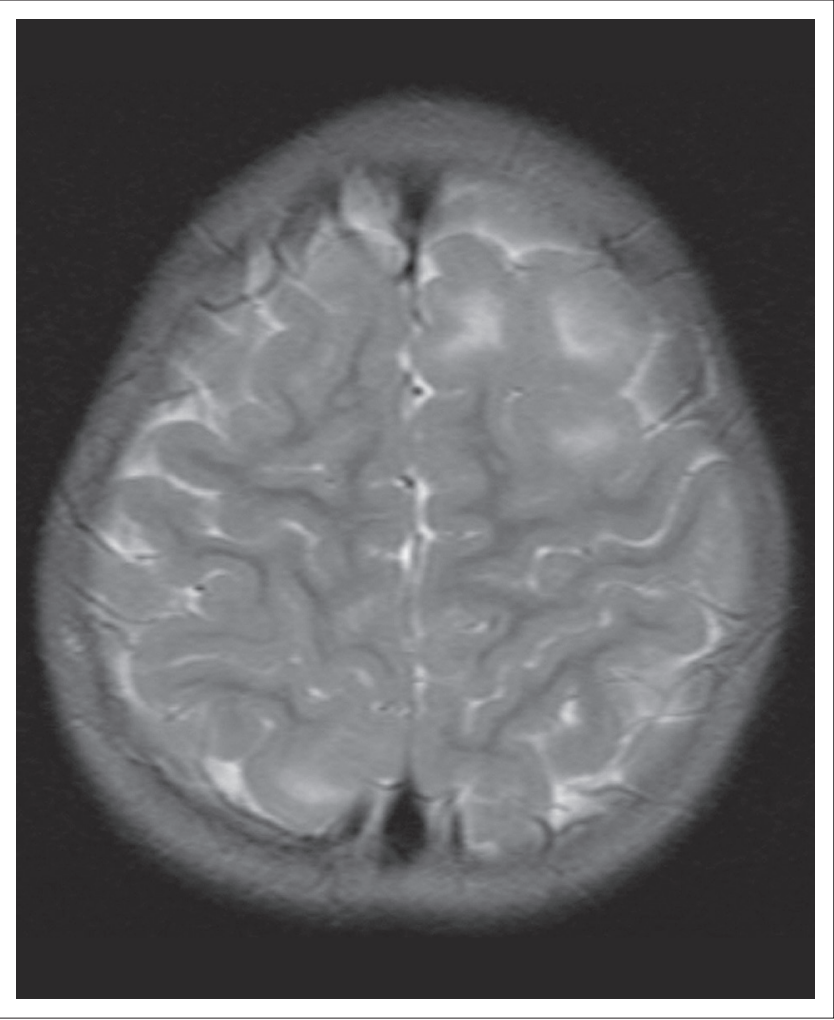

FIGURE 1: Axial T2-weighted MR image.

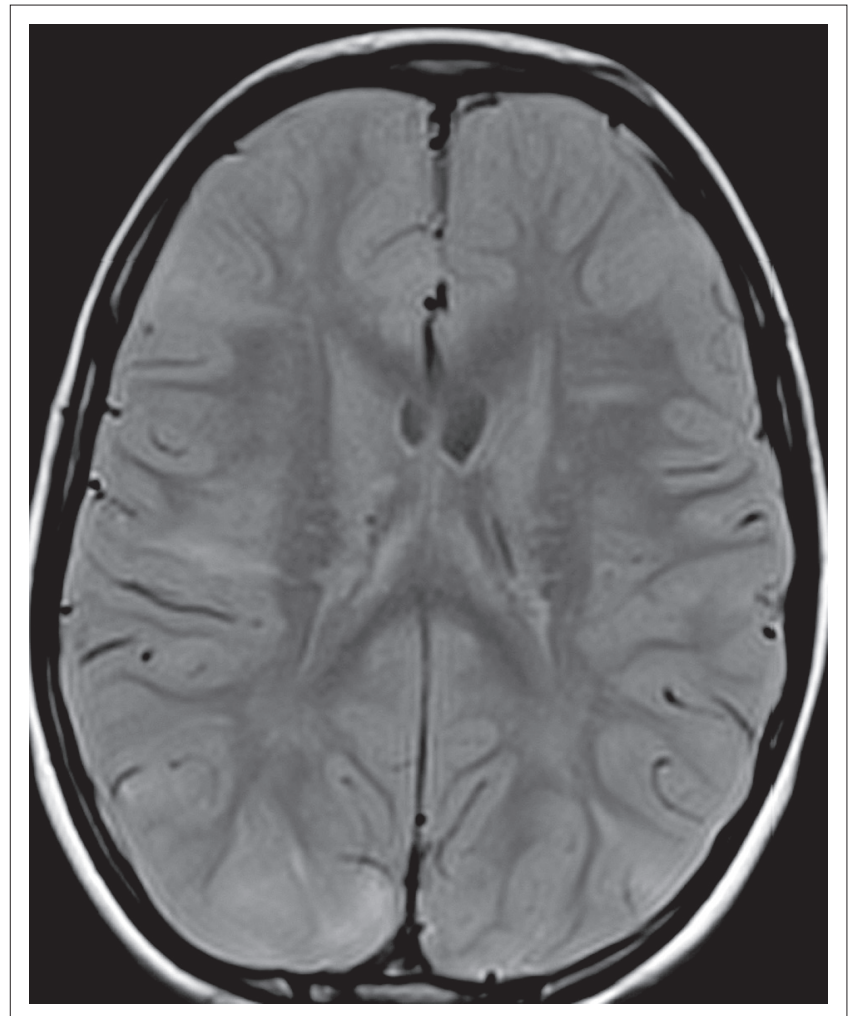

FIGURE 2: Axial FLAIR MR image.

\begin{tabular}{|c|c|c|}
\hline \multirow{3}{*}{\multicolumn{2}{|c|}{ Read online: }} & Author: Shalendra K. Misser ${ }^{1}$ \\
\hline & & Affiliation: ${ }^{1}$ Lake Smit and Partners Inc, Durban, South Africa \\
\hline & & Correspondence to: Shalendra Misser \\
\hline \multirow{4}{*}{ 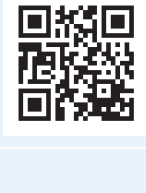 } & Scan this QR & Email: misser@lakesmit.co.za \\
\hline & $\begin{array}{l}\text { Code with your } \\
\text { smart phone or }\end{array}$ & Postal address: Private Bag X08, Overport 4067, Durban, South Africa \\
\hline & $\begin{array}{l}\text { mobile device } \\
\text { to read online. }\end{array}$ & $\begin{array}{l}\text { How to cite this article: Misser, SK. Paediatric Neuroimaging Quiz Case. S Afr J Rad. 2015;19(2); Art. \#873, } 3 \text { pages. } \\
\text { http://dx.doi.org/10.4102/saj.v19i2.873 }\end{array}$ \\
\hline & & $\begin{array}{l}\text { Copyright: ( ) 2015. The Authors. Licensee: AOSIS OpenJournals. This work is licensed under the Creative Commons } \\
\text { Attribution License. }\end{array}$ \\
\hline
\end{tabular}




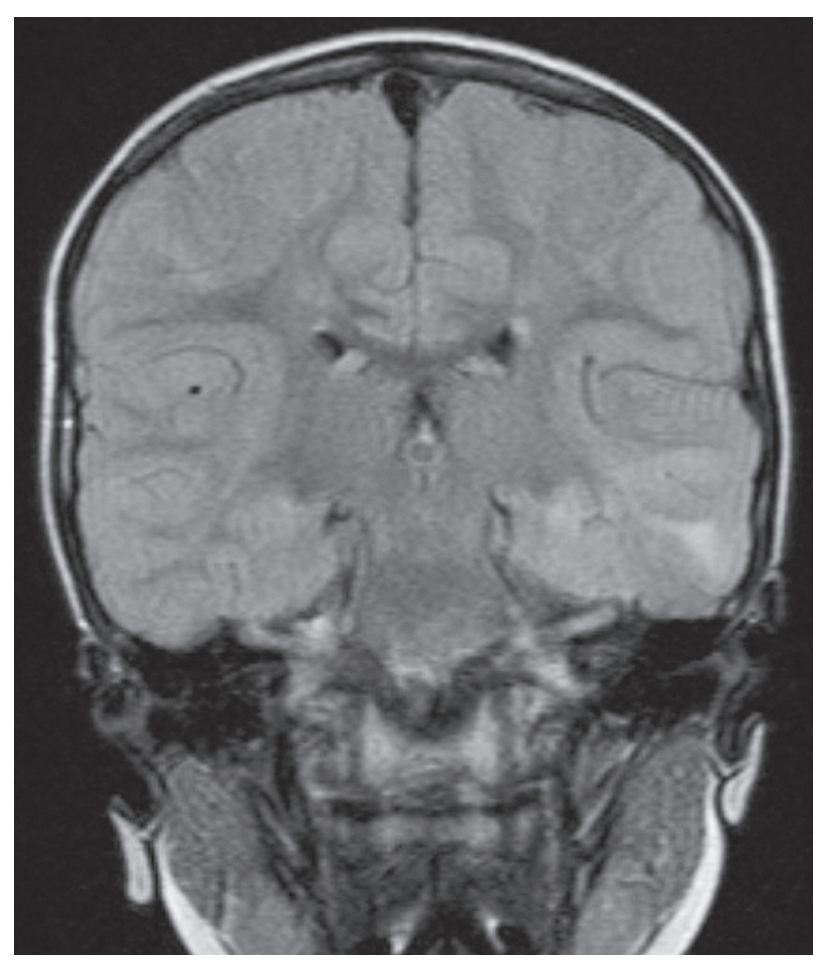

FIGURE 3: Coronal FLAIR MR image.

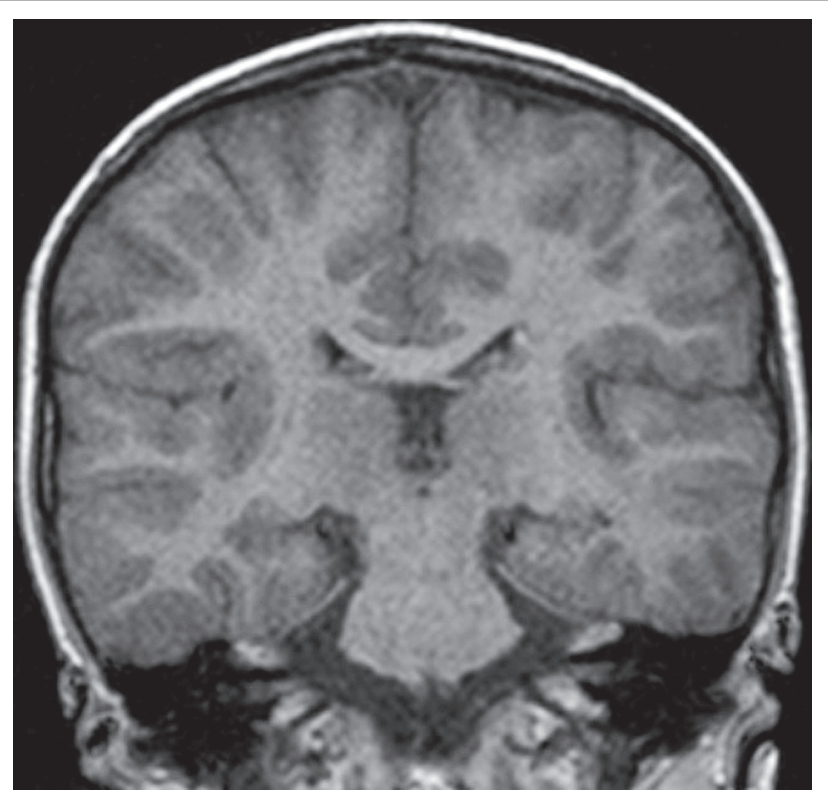

FIGURE 5: Coronal T1-weighted MR image.

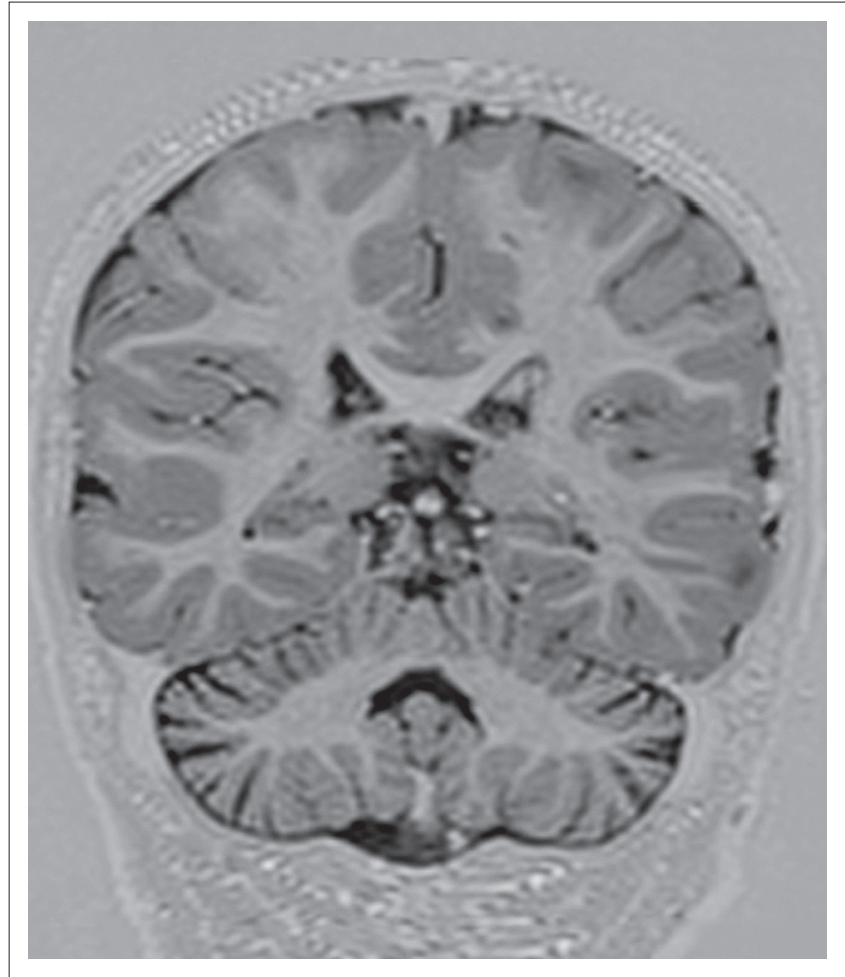

FIGURE 4: Coronal T1-Inversion Recovery MR image.

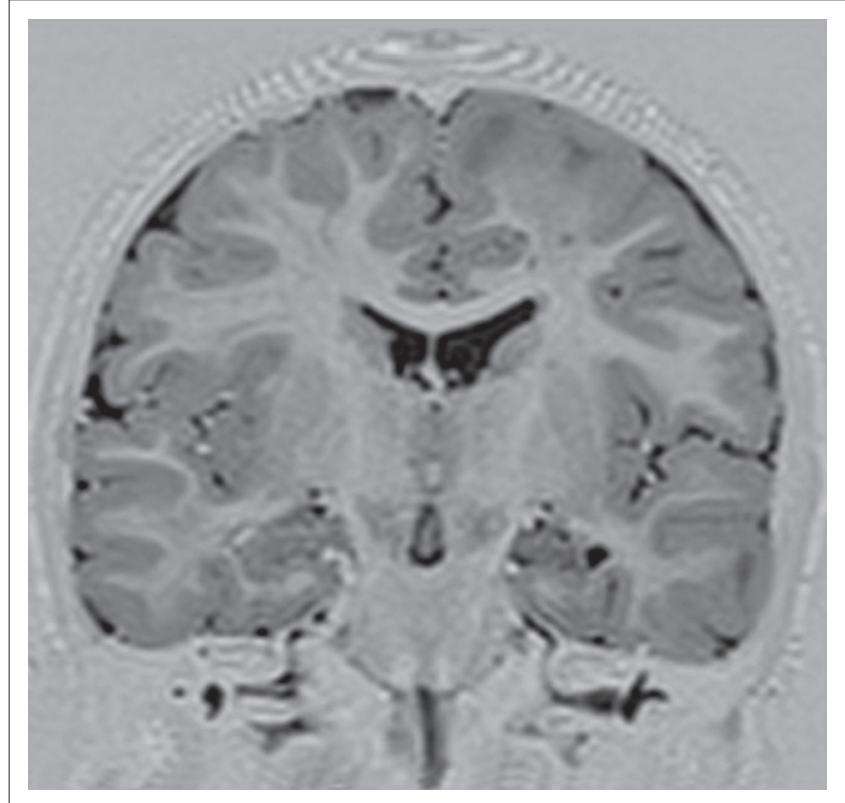

FIGURE 6: Coronal T1 Inversion Recovery MR image. 


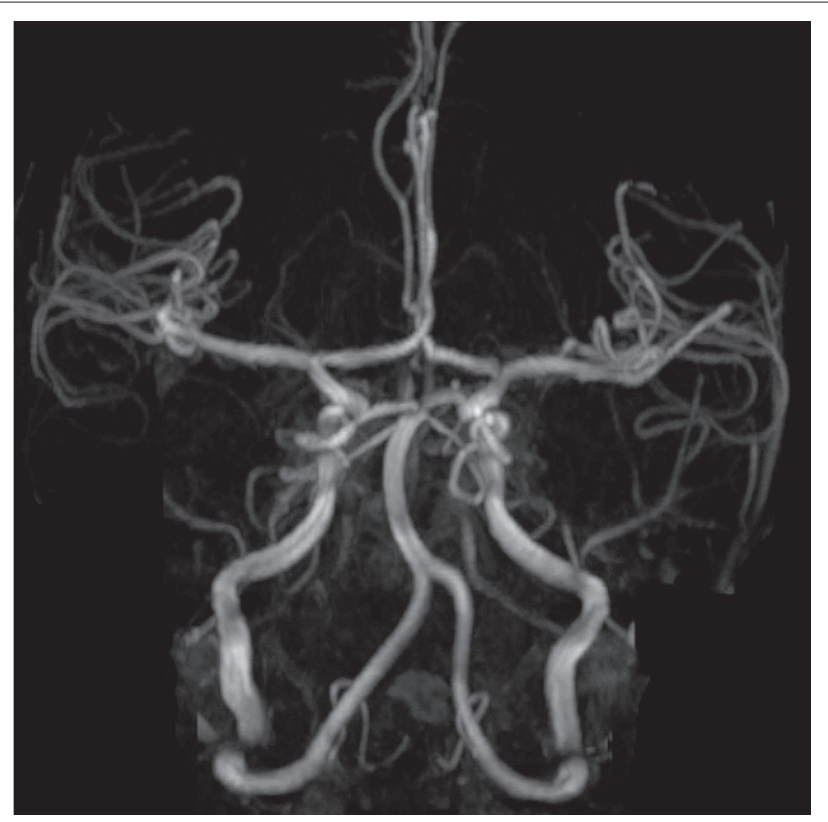

FIGURE 7: MR Angiography image of the circle of willis.
Describe the relevant imaging findings and formulate the most appropriate clinical diagnosis. Please submit your response to misser@lakesmit.co.za not later than 30 November 2015. The winning respondent will receive a R1000 award from the RSSA. A detailed diagnosis and discussion will be presented in the next issue of the SAJR. 